\title{
Bacterial community shift for monitoring the co-composting of oil palm empty fruit bunch and palm oil mill effluent anaerobic sludge
}

\begin{abstract}
A recently developed rapid co-composting of oil palm empty fruit bunch (OPEFB) and palm oil mill effluent (POME) anaerobic sludge is beginning to attract attention from the palm oil industry in managing the disposal of these wastes. However, a deeper understanding of microbial diversity is required for the sustainable practice of the co-compositing process. In this study, an in-depth assessment of bacterial community succession at different stages of the pilot scale co-composting of OPEFB-POME anaerobic sludge was performed using 454pyrosequencing, which was then correlated with the changes of physicochemical properties including temperature, oxygen level and moisture content. Approximately 58,122 of $16 \mathrm{~S}$ rRNA gene amplicons with more than 500 operational taxonomy units (OTUs) were obtained. Alpha diversity and principal component analysis (PCoA) indicated that bacterial diversity and distributions were most influenced by the physicochemical properties of the cocomposting stages, which showed remarkable shifts of dominant species throughout the process. Species related to Devosia yakushimensis and Desemzia incerta are shown to emerge as dominant bacteria in the thermophilic stage, while Planococcus rifietoensis correlated best with the later stage of co-composting. This study proved the bacterial community shifts in the co-composting stages corresponded with the changes of the physicochemical properties, and may, therefore, be useful in monitoring the progress of cocomposting and compost maturity.
\end{abstract}

Keyword: Co-composting; Bacterial community structure; Oil palm empty fruit bunch; Palm oil mill effluent anaerobic sludge; Pyrosequencing 